\title{
Candidate Genes and Risk for CP: A Population-Based Study
}

\author{
YVONNE W. WU, LISA A. CROEN, ANDREW VANDERWERF, AMY A. GELFAND, AND ANTHONY R. TORRES
}

\author{
Departments of Neurology and Pediatrics [Y.W.W., A.A.G.], University of California, San Francisco, California 94143; Division of \\ Research [L.A.C.], Kaiser Permanente, Oakland, California 94612; Department of Bioengineering and Center for Persons With
} Disabilities [A.V., A.R.T.], Utah State University, Logan, Utah 84321

\begin{abstract}
Studies suggest that genetic polymorphisms may increase an individual's susceptibility to CP. Most findings have yet to be corroborated in an independent cohort. This case-control study is nested within all 334,333 infants $\geq 36$ wk gestation born at Kaiser Permanente Medical Care Program, 1991-2002. We included only non-Hispanic whites who had a neonatal blood sample available. Case patients $(n=138)$ were identified from medical records to have spastic or dyskinetic CP. Controls $(n=165)$ were randomly selected from the population. We genotyped polymorphisms previously associated with CP: inducible NOS (iNOS)-231, apolipoprotein E (apoE) $\epsilon 2$ and $\epsilon 4$ alleles, TNF- $\alpha-308$, IL-8 - 251, lymphotoxin 60 , endothelial NOS -922, endothelial protein C receptor 219, mannose-binding lectin 54 and 52, factor V Leiden, methyltetrahydrofolate reductase 1298 and 667, prothrombin 20210, and platelet activator inhibitor 11053. Similar to previous reports, the iNOS-231 T allele $(25.7$ versus $18.9 \%, p=0.04)$ and the apoE $\epsilon 4$ allele (19.3 versus $13.2 \%$, $p=0.04)$ were more common in patients with $\mathrm{CP}$ than in controls. However, there was no statistically significant association between any genetic polymorphism and $\mathrm{CP}$ after correction for multiple comparisons. (Pediatr Res 70: 642-646, 2011)
\end{abstract}

$\mathrm{C}$ is a group of nonprogressive motor impairment syndromes caused by lesions of the brain arising early in development (1). The etiology of $\mathrm{CP}$ remains unclear in most cases. Alterations in genes involved in inflammation and coagulation have been implicated as risk factors for CP. More than 20 studies of CP have evaluated single-nucleotide polymorphisms (SNPs) in genes that regulate the inflammatory and coagulation cascades, and polymorphisms in more than 15 genes have been associated with CP (2-12). However, genetic association studies of $\mathrm{CP}$ have been hampered by multiple comparisons, small sample size and population heterogeneity, thus leading to inconsistent findings $(3,12-14)$.

A promoter region polymorphism in the IL- 6 gene has been associated with CP both in Australia (4) and in our California population (5). The $\epsilon 4$ allele of the apolipoprotein $\mathrm{E}$ (apoE) gene has also been associated with $\mathrm{CP}$ in more than one population $(15,16)$, although not all studies have supported this finding $(17,18)$. Few genetic studies of CP have been conducted in the United States, and the majority of findings have yet to be corroborated in an independent cohort. Therefore, we set out to validate previously described genetic

Received April 6, 2011; accepted June 28, 2011.

Correspondence: Yvonne Wu, M.D., UCSF Child Neurology, 350 Parnassus Avenue, Ste 609, San Francisco, CA 94143; e-mail: wuy@neuropeds.ucsf.edu

Supported by the Cerebral Palsy Institute, NIH K02 NS46688, and the United Cerebral Palsy Foundation.

The authors report no conflicts of interest. associations with CP, within a large California birth cohort of term and near-term infants.

\section{METHODS}

Our study population consists of all singleton live births $\geq 36 \mathrm{wk}$ gestation born between January 1, 1991, and December 31, 2002, in the Kaiser Permanente Medical Care Program (KPMCP), a large managed care organization. The members of KPMCP are demographically similar to the California population, except that the very poor and very wealthy are under-represented (19).

Children with $\mathrm{CP}$ were identified from the study population as previously reported (20). After electronically searching KPMCP records for physician diagnoses of "CP," "paresis," and "gait abnormality," a single child neurologist (Y.W.W.) reviewed medical records to confirm the diagnosis of CP. We defined $\mathrm{CP}$ as a nonprogressive congenital motor dysfunction with examination findings of increased tone (spasticity, rigidity, dystonia) or choreoathetosis (21). Children with hypotonia, ataxia, myopathy, neural tube defect, genetic syndrome, and chromosomal anomaly were excluded (22). We defined mild disability as minimal functional limitation; moderate disability as diminished use of the most affected limb; and severe disability as the lack of any functional use of the most affected limb (23).

Case selection. To control for racial heterogeneity in SNP frequencies, our study included only non-Hispanic whites (referred to as "whites" in the remainder of the article). Of the 377 infants with $\mathrm{CP}$ identified in the birth cohort (20), we excluded 74 infants from this study for the following reasons: brain malformation (39), resolution of motor abnormality by $3 \mathrm{y}$ of age (24), unclear severity of CP (7), and congenital cytomegaloviral infection (4). Case infants whose newborn blood samples were unavailable for study (47), whose blood samples were taken after having received a blood transfusion (5), or whose blood samples were mislabeled (1) were also excluded. After excluding 112 nonwhites, the remaining 138 infants with CP represent the cases in this study.

Control selection. For the larger study, we randomly selected 652 control infants from the KPMCP birth cohort. Control infants with missing (64) or mislabeled (1) newborn blood samples were excluded. We were unable to genotype all control subjects because of financial constraints and randomly excluded an additional 282 control infants. After excluding 140 nonwhites, the remaining 165 infants comprised the control group of this study.

Blood sample collection. Stored neonatal blood specimens were retrieved from the newborn screening specimen archives maintained by the California Department of Public Health. Newborn blood specimens are collected on Guthrie card filter paper and allowed to dry at room temperature before submission for routine genetic and metabolic screening. On completion of the screening tests, remaining blood samples are stored at $-15^{\circ} \mathrm{C}$ in a single refrigerated warehouse.

Blood spot Guthrie cards were punched with a 3-mm paper punch in a laminar flow hood under aseptic conditions. The Qiagen QIAamp blood kit 51161 (Valencia, CA) was used for preparing genomic DNA from the blood spots. Two 3-mm punches from each subject were placed into a 96-well plate and incubated at $56[\mathrm{dg}] \mathrm{C}$ for $1 \mathrm{~h}$ in Qiagen buffer and Proteinase K enzyme from Amresco (Solon, OH). Quantitation of genomic DNA was performed using the Quant-iT DNA Assay Kit (24) (Q33130) from Molecular Probes (Eugene, OR) with lambda DNA as a standard. PicoGreen fluorescence was measured with a Synergy HT microplate reader (BIO-TEK, Winooski, VT).

Abbreviations: KPMCP, Kaiser Permanente Medical Care Program; MBL, mannose binding lectin; MTHFR, methyltetrahydrofolate reductase; SNP, single-nucleotide polymorphism 
Table 1. Characteristics of 138 white infants with $C P$ who were born $\geq 36$ wk gestation

\begin{tabular}{lrr}
\hline & $\mathrm{N}$ & $\%$ \\
\hline Evaluated by a neurologist & 113 & 82 \\
CP type* & 125 & 91 \\
$\quad$ Spastic & 11 & 8 \\
Choreoathetotic & 5 & 4 \\
$\quad$ Dystonic or rigid & 57 & \\
Limb involvement & 38 & 28 \\
$\quad$ Hemiparesis & 34 & 25 \\
Quadriparesis & 2 & 1 \\
Paraparesis & 7 & 5 \\
Monoparesis & & \\
$\quad$ Unclear & 53 & 38 \\
Severity of motor impairment & 53 & 38 \\
$\quad$ Mild & 32 & 23 \\
Moderate & \\
$\quad$ Severe &
\end{tabular}

* Note that a child may have more than one type of CP.

Genotyping assays. All genotyping was performed blind to case status and clinical history. Commercial Applied Biosystems Taqman SNP probes (Foster City, CA) were used to genotype SNPs using $0.5 \mathrm{ng}$ of genomic DNA. We genotyped the following SNPs that have been previously associated with CP: TNF- $\alpha$-308 (rs1800629) (8), IL-8 (IL-8)-251 (rs4073) (6), lymphotoxin 60 (rs1041981) (6,11), endothelial NOS (eNOS)-922 (rs1800779) (11), inducible NOS (iNOS)-231 (rs1137933) (6), endothelial protein C receptor (EPCR) 219 (rs867186) (6), mannose-binding lectin (MBL) 54 (rs1800450) and 52 (rs5030737) (8), factor V Leiden (FVL) 506 (rs6025) (10), methyltetrahydrofolate reductase (MTHFR) 1298 (rs1801131) and 667 (rs1801133) (10), prothrombin 20210 (rs1799963) (10), platelet activator inhibitor (PAI-1) 11053 (rs7242) (11), and apolipoprotein E (apo E) $\varepsilon 2$ and $\varepsilon 4$ alleles (rs429358 and rs7412) $(15,16,18)$. The IL-6-174 polymorphism was previously studied in this population (5) and therefore was not included in this study.

Standard Taqman PCRs were performed using an Applied Biosystems 7500 Fast system AB 96-well optical plates (plates P/N 4366932). The reactions were designed according to the Applied Biosystems SNP assay protocol in $10 \mu \mathrm{L}$ volumes. Each reaction was done in a single well because of limited amounts of genomic DNA. Results from all experiments were obtained from Applied Biosystems SDS software v2.0 and Copy Caller software v1.0.

Data analysis. We defined SNP genotypes as follows: common homozygote $=$ two copies of the common allele; heterozygote $=$ one copy of each allele; and rare homozygote $=$ two copies of the rare allele. The goal of this study was to replicate previously reported genetic associations with $\mathrm{CP}$. Therefore, using logistic regression, we determined ORs and 95\% CI using the three genetic comparisons that were most commonly reported in the literature: 1) rare homozygote versus common homozygote; 2) heterozygote versus common homozygote; and 3 ) heterozygote or rare homozygote versus common homozygote. We also compared allele frequencies between the case and control infants. Using $\alpha=0.05$, we had adequate power $(\beta>0.9)$ to detect previously described effect sizes for SNPs in the following genes: eNOS, MBL 52, MTHFR 677, MTHFR 1298, and apoE E2 and E4 alleles. We had marginal power $(\beta=0.75)$ to detect previously reported effect sizes for the genes TNF- $\alpha$ and IL-8. Our study had inadequate power $(\beta=$ $0.21-0.65)$ to detect previously described effect sizes in the remaining gene polymorphisms studied. We used a Bonferroni correction to adjust for the multiple case-control comparisons; a $p$ value of 0.001 was considered statistically significant after adjusting for multiple genetic analyses of 15 SNPs. ORs are close approximations of the relative risk, because the outcome of $\mathrm{CP}$ is rare in term infants. All analyses were performed using STATA (25) statistical software package.

Study procedures and a waiver of consent were approved by the Institutional Review Boards at KPMCP, UT State University, University of California, San Francisco, and by the California Committee for the Protection of Human Subjects.

\section{RESULTS}

Among 334,333 newborn infants, we identified 377 with spastic or dyskinetic CP. The prevalence of CP among term and near-term infants was 1.1 per 1000 live births. After
Table 2. Genotype distributions among 165 white control infants without $C P$

\begin{tabular}{|c|c|c|c|c|}
\hline Gene & Polymorphism & $\begin{array}{l}\text { Common } \\
\text { homozygote } \\
(\%)\end{array}$ & $\begin{array}{c}\text { Heterozygote } \\
(\%)\end{array}$ & $\begin{array}{c}\text { Rare } \\
\text { homozygote } \\
(\%)\end{array}$ \\
\hline TNF-alpha & $-308 \mathrm{G} / \mathrm{A}$ & 67.9 & 30.3 & 1.8 \\
\hline IL-8 & $-251 \mathrm{~A} / \mathrm{T}$ & 28.8 & 49.1 & 22.1 \\
\hline Lymphtotoxin & $60 \mathrm{C} / \mathrm{A}$ & 38.3 & 50.6 & 11.1 \\
\hline eNOS & $-922 \mathrm{~A} / \mathrm{G}$ & 41.5 & 47.6 & 11.0 \\
\hline iNOS & $-231 \mathrm{C} / \mathrm{T}$ & 65.9 & 30.5 & 3.7 \\
\hline EPCR & 219 G/A & 78.1 & 20.7 & 1.2 \\
\hline MBL & $54 \mathrm{G} / \mathrm{A}$ & 70.6 & 28.2 & 1.2 \\
\hline MBL & $52 \mathrm{~A} / \mathrm{C}$ & 85.9 & 13.5 & 0.6 \\
\hline FVL & $506 \mathrm{G} / \mathrm{A}$ & 67.9 & 30.3 & 1.8 \\
\hline MTHFR & $677 \mathrm{C} / \mathrm{T}$ & 33.5 & 52.8 & 13.7 \\
\hline MTHFR & $1298 \mathrm{~A} / \mathrm{C}$ & 50.6 & 42.0 & 7.4 \\
\hline Prothrombin & $20210 \mathrm{G} / \mathrm{A}$ & 98.2 & 1.8 & 0.0 \\
\hline PAI-1 & $11053 \mathrm{G} / \mathrm{T}$ & 34.4 & 45.0 & 20.6 \\
\hline ApoE & $\varepsilon 3 / \varepsilon 4$ & 66.3 & 20.3 & 3.1 \\
\hline ApoE & $\varepsilon 3 / \varepsilon 2$ & 66.3 & 12.3 & 0.0 \\
\hline
\end{tabular}

applying exclusion criteria, our study included 138 case and 165 control infants. CP was diagnosed by a neurologist in most cases $(82 \%)$. Spastic hemiparesis $(39 \%)$ was the most common CP type, followed by spastic quadriparesis (25\%). Sixty-one percent of patients had moderate to severe functional impairment (Table 1).

The genotyping yield was $99 \%$ for all polymorphisms, with the exception of PAI-1 that was successfully genotyped in only $96 \%$ of patients. There was no difference in the rate of successful genotyping between case and control infants. Among the control population, all allele frequencies were in Hardy-Weinberg equilibrium. Control population genotype distributions are listed in Table 2.

First, we compared the rate of $\mathrm{CP}$ among children with two copies of the rare allele with children who were homozygous for the common allele; unlike previous reports whose findings are summarized in Table 3, none of the genetic polymorphisms in our study were associated with increased risk of $\mathrm{CP}$ even without adjustment for multiple comparisons (Table 3). The MTHFR 677 polymorphism was associated with a reduced risk of $\mathrm{CP}(\mathrm{OR}, 0.4 ; 95 \% \mathrm{CI}, 0.2-0.9)$, but this was also no longer significant after adjusting for multiple comparisons.

We then studied the relationship between genetic polymorphisms and $\mathrm{CP}$ by comparing heterozygotes to common homozygotes, as was done in previous studies (Table 3) $(6,8,10)$. In these analyses, iNOS-231 (OR, 1.9; 95\% CI, 1.2-3.1) and apoE $\epsilon 4$ (OR, 1.7; 95\% CI, 1.01-2.9) were associated with increased risk of $\mathrm{CP}$, but these findings were not significant after adjustment for multiple comparisons. Finally, we compared the rate of $\mathrm{CP}$ in children with at least one copy of the rare allele with children carrying two copies of the common allele. No other associations with $\mathrm{CP}$ were found when the genetic variants were analyzed in a dominant genetic comparison (data not shown).

When we compared allele frequencies between case and control infants, we found that the iNOS T allele (25.7 versus $18.9 \%, p=0.04)$ and the apoE $\epsilon 4$ allele (19.3 versus $13.2 \%$, $p=0.04)$ were more common in case than control infants. 
Table 3. Summary of previously reported associations between CP and polymorphisms in inflammatory, thrombotic, and apolipoprotein E genes, juxtaposed with results of similar analyses performed in this study

\begin{tabular}{|c|c|c|c|c|c|c|c|c|c|}
\hline \multirow[b]{2}{*}{ Gene (codon) } & \multicolumn{6}{|c|}{ Previous studies } & \multicolumn{3}{|c|}{$\begin{array}{c}\text { Present study } \\
N=138 \text { White, } \geq 37 \text { wk }\end{array}$} \\
\hline & $\begin{array}{l}\mathrm{CP} \\
(\mathrm{N})\end{array}$ & $\begin{array}{l}\text { GA } \\
\text { (wk) }\end{array}$ & Demographics & $\begin{array}{l}\mathrm{CP} \\
\text { type }\end{array}$ & $\begin{array}{c}\text { Rare homozygote } \\
\text { vs. common } \\
\text { homozygote } \\
\text { OR }(95 \% \text { CI) }\end{array}$ & $\begin{array}{l}\text { Heterozygote } \\
\text { vs. common } \\
\text { homozygote } \\
\text { OR }(95 \% \mathrm{CI})\end{array}$ & $\begin{array}{l}\mathrm{CP} \\
\text { type }\end{array}$ & $\begin{array}{c}\text { Rare homozygote } \\
\text { vs. common } \\
\text { homozygote } \\
\text { OR }(95 \% \text { CI })\end{array}$ & $\begin{array}{l}\text { Heterozygote } \\
\text { vs. common } \\
\text { homozygote* } \\
\text { OR }(95 \% \mathrm{CI})\end{array}$ \\
\hline \multicolumn{10}{|l|}{ Inflammatory } \\
\hline TNF-alpha-308 (8) & 65 & $\geq 37$ & Whites & QP & $0.0(0.0-1.6)$ & $1.8(1.04-3.2)$ & All & $1.9(0.4-8.0)$ & $0.8(0.5-1.3)$ \\
\hline \multirow[t]{2}{*}{ IL-8-251 (6) } & 153 & $<37$ & Whites & All & $2.4(1.3-4.4)$ & $2.0(1.2-3.5) \dagger$ & All & $1.3(0.7-2.5)$ & $1.1(0.7-1.9)$ \\
\hline & 121 & All & Whites & DP & $0.8(0.5-1.3) \dagger$ & $1.9(1.2-3.1)$ & DP & $1.7(0.6-4.9)$ & $1.5(0.6-3.9)$ \\
\hline \multirow{4}{*}{$\begin{array}{l}\text { Lymphtotoxin } 60 \\
\quad(6,11)\end{array}$} & 356 & All & Whites & All & $1.5(1.01-2.18)$ & $1.2(0.9-1.6) \dagger$ & All & $1.3(0.6-2.7)$ & $0.8(0.5-1.3)$ \\
\hline & 118 & All & Whites & HP & $1.8(1.02-3.23)$ & $1.3(0.9-2.1) \dagger$ & HP & $0.9(0.3-1.4)$ & $0.6(0.3-1.2)$ \\
\hline & 110 & All & Whites & QP & $1.9(1.01-3.3)$ & $1.5(0.9-2.4) \dagger$ & QP & $1.5(0.5-4.4)$ & $1.0(0.5-2.1)$ \\
\hline & 96 & $<32$ & Whites, Hispanics & All & $0.4(0.1-1.2) \dagger$ & $1.4(0.8-2.6) \dagger$ & DP & $1.6(0.5-4.8)$ & $0.9(0.4-2.0)$ \\
\hline \multirow[t]{2}{*}{ eNOS-922 $(6,11)$} & 96 & $<32$ & Whites, Hispanics & All & $0.5(0.1-1.6) \dagger$ & $2.2(1.2-4.0) \dagger$ & All & $1.4(0.7-2.9)$ & $0.9(0.6-1.5)$ \\
\hline & 126 & All & Whites & DP & $0.5(0.3-0.95)$ & $0.7(0.5-1.1) \dagger$ & DP & $1.7(0.6-5.0)$ & $0.7(0.3-1.6)$ \\
\hline iNOS-231 (6) & 180 & $\geq 37$ & Whites & All & $0.9(0.5-1.7) \dagger$ & $1.6(1.1-2.2)$ & All & $1.01(0.3-3.7)$ & $1.9(1.2-3.1)$ \\
\hline \multirow[t]{2}{*}{ EPCR 219 (6) } & 190 & $\geq 37$ & Whites & All & $0(0-2.3) \dagger$ & $1.6(1.1-2.3)$ & All & $1.2(0.2-8.5)$ & $0.9(0.5-1.6)$ \\
\hline & 127 & All & Whites & DP & $0.9(0.02-6.4) \dagger$ & $1.9(1.2-3.1)$ & DP & $2.4(0.2-27.1)$ & $0.8(0.3-2.2)$ \\
\hline \multirow[t]{2}{*}{ MBL 54 (8) } & 49 & All & Whites & DP & $0.7(0.1-3.2)$ & $1.6(1.1-2.4)$ & All & $2.8(0.5-15.0)$ & $0.7(0.4-1.3)$ \\
\hline & 21 & $\geq 37$ & Whites & DP & $1.2(0.03-8.1)$ & $2.2(1.1-4.2)$ & DP & $2.2(0.2-25.3)$ & $0.6(0.2-1.5)$ \\
\hline MBL 52 (8) & 65 & $\geq 37$ & Whites & QP & $0(0-18.8)$ & $3.8(1.03-11.1)$ & All & $1.2(0.1-18.9)$ & $0.9(0.4-1.7)$ \\
\hline \multicolumn{10}{|l|}{ Thrombotic } \\
\hline FVL (506) & 1 & NA & NA $\ddagger$ & HP & NA & NA & All & - & $0.8(0.4-1.8)$ \\
\hline \multirow[t]{2}{*}{ MTHFR 677 (10) } & 58 & $32-36$ & Whites & All & $2.6(1.1-5.7)$ & $1.9(1.01-3.7)$ & All & $0.4(0.2-0.9)$ & $0.6(0.4-1.04)$ \\
\hline & 58 & $<32$ & Whites & DP & $2.8(1.2-6.1)$ & $1.6(1.02-2.5)$ & DP & $0.5(0.1-2.0)$ & $0.8(0.4-1.7)$ \\
\hline MTHFR 1298 (10) & 20 & $32-36$ & Whites & DP & $0.5(0.1-2.3)$ & $0.2(0.02-0.07)$ & All & $0.6(0.7-3.8)$ & $0.3(0.8-2.0)$ \\
\hline Prothrombin 20210 (10) & 20 & $32-36$ & Whites & DP & $0(0.0-67.5)$ & $4.3(0.8-16.6) \dagger \S$ & All & - & $0.5(0.1-2.1)$ \\
\hline PAI-1 11053 (6) & 150 & All & White Girls & All & $1.9(1.1-3.4)$ & $1.6(0.9-2.6) \dagger$ & All & $1.0(0.5-2.0)$ & $1.2(0.7-2.1)$ \\
\hline \multicolumn{10}{|l|}{ Apolipoprotein E } \\
\hline \multirow[t]{2}{*}{$\epsilon 4$ allele $(15,16)$} & 209 & All & $\begin{array}{l}\text { White, Hispanic, } \\
\text { black }\end{array}$ & All & $2.9(0.5-30.8) \dagger$ & $3.4(1.4-8.7)$ & All & $1.6(0.5-5.6)$ & $1.7(1.01-2.9)$ \\
\hline & 40 & All & Brazilian & All & Unknown & $5.8(1.3-34.8) \dagger$ & HP & $2.1(0.5-9.1)$ & $1.9(0.96-3.8)$ \\
\hline \multirow[t]{3}{*}{$\epsilon 2$ allele $(16-18)$} & 209 & All & $\begin{array}{l}\text { White, Hispanic, } \\
\text { black }\end{array}$ & All & Unknown & $12.0(1.6-247)$ & All & - & $1.1(0.6-2.1)$ \\
\hline & 106 & $<32$ & Whites & All & Unknown & $3.5(1.1-12.7)$ & HP & - & $1.3(0.6-3.1)$ \\
\hline & 243 & All & Brazilian & All & Unknown & $2.8(1.01-7.66)$ & DP & - & $1.2(0.4-3.6)$ \\
\hline
\end{tabular}

Significant findings without adjustment for multiple comparisons highlighted in bold.

* Note that none of the genetic associations were statistically significant after adjusting for multiple comparisons. Because of space constraints, this table does not include dominant genetic analyses (i.e. rare homozygote or heterozygote, compared with common homozygote). We found no significant associations when data were analyzed with dominant genetic comparisons.

$\dagger$ These ORs were calculated from the raw data provided in published articles.

\$ NA, not available. An association between FVL and CP has only been reported in case reports and case series, and therefore no risk ratios are available. $\S$ The controls used in this calculation were term infants $\geq 37$ wk gestation.

DP, diplegic; HP, hemiplegic; QP, quadriplegic; All, DP + HP + QP. Note that when a polymorphism was not associated with overall CP, there was similarly no association found between that polymorphism and any subtype of $\mathrm{CP}$.

However, these differences were no longer statistically significant after correction for multiple comparisons.

We stratified our genetic analyses by CP subtype to compare our findings with previous reports (Table 3). No additional information was gleaned from these stratified analyses; i.e. when there was no association between a genetic polymorphism and $\mathrm{CP}$, there was similarly no association seen between that genetic polymorphism and any subset of $\mathrm{CP}$, including diplegic, hemiplegic, or quadriplegic $\mathrm{CP}$.

\section{DISCUSSION}

In a study of non-Hispanic white infants born at or near term, we found an increase in the frequency of the apoE $\epsilon 4$ and iNOS-231 $\mathrm{T}$ alleles in children with $\mathrm{CP}$ that was of borderline significance. These associations had small effect sizes, and after adjusting for multiple comparisons in an attempt to avoid false-positive findings, we found that these associations were no longer statistically significant.

Genotype-phenotype associations have been observed in many complex diseases; yet most findings have been difficult to replicate (26-28). CP is a complex and heterogeneous condition, and it is not surprising that genetic association studies have produced inconsistent results. Exploratory studies evaluating a large panel of SNPs often involve numerous statistical analyses stratified by CP subtype, gender, ethnicity, and GA. Such studies also use multiple control groups and 
perform a variety of genetic comparisons. Thus, in the absence of statistical adjustment for multiple comparisons, exploratory studies testing between 93 and 720 hypotheses $(4,6,8,10,11)$ would be expected to yield $\sim 5$ to 30 genetic associations from chance alone.

Other factors that might contribute to the inconsistent results across studies include small sample size, population heterogeneity, differences in gene-environment interactions, and publication bias $(3,26)$. It is also important to remember that $\mathrm{CP}$ is a heterogeneous disorder that results from numerous causal pathways leading to a variety of different types of brain injury, and that lumping all patients with $\mathrm{CP}$ into one group further limits our ability to discern meaningful genotypephenotype associations. Our study is limited by the inclusion of only white infants born at or near term who have spastic or dyskinetic CP. Therefore, our study is not a direct replication of all previous reports, because several past studies have included preterm and nonwhite infants. Furthermore, we did not perform haplotype analyses or evaluate the presence of viral infections that might modify the relationship between genetic variants and CP $(9,29)$.

The weak statistical associations identified in our cohort did not persist after adjustment for multiple comparisons. Given the large number of hypotheses that we tested, it was important to perform statistical adjustment to avoid type 1 error. Although we conservatively used the Bonferroni test, any method of adjustment for multiple comparisons would have rendered our findings insignificant, given the $p$ values of 0.04 for the uncorrected genetic associations. However, the weak associations found between the apoE $\epsilon 4$ and iNOS-231 T alleles and $\mathrm{CP}$ are similar to previous findings in other populations $(6,15,16)$ and therefore deserve further discussion.

The relationship between the apoE $\epsilon 4$ allele and $\mathrm{CP}$ is controversial. Two studies have found a modest increased risk of CP among children who carry at least one $\epsilon 4$ allele $(15,16)$, but a recent meta-analysis suggests that no significant association exists (3). Apolipoprotein $\mathrm{E}$ is a lipid transport protein widely expressed in the brain. Carriage of at least one copy of the $\epsilon 4$ allele is associated with Alzheimer disease (30) and ischemic stroke in adults $(31,32)$. Children with the $\epsilon 4$ allele have been shown to exhibit worse neurobehavioral performance and higher birth complication rates (33). We found that children with $\mathrm{CP}$ had a higher frequency of carrying an apoE $\epsilon 4$ allele, but further large-scale studies will be necessary to determine whether this trend reflects a biologically meaningful relationship.

Similar to previous studies, we found that children with $\mathrm{CP}$ were more likely to have a copy of the iNOS-231 $\mathrm{T}$ allele, although this finding was not statistically significant after adjustment for multiple comparisons. The iNOS gene was first evaluated in relation to $\mathrm{CP}$ because of its role in cardiovascular regulation and ischemic and inflammatory brain injury $(2,6,34)$. Overexpression of iNOS in the brain has been reported in newborn periventricular white matter injury (35) and in adult stroke (36). In a rat model of newborn brain injury caused by intrauterine infection, iNOS was found to be a key mediator of oligodendrocyte injury (34). Studies comparing iNOS production in patients with and without CP may help us better understand whether genetic variation in the iNOS gene is related to $\mathrm{CP}$ risk.

The IL-6-174 polymorphism has been linked with several adverse perinatal neurologic outcomes including CP (4,5), periventricular white matter injury (37), and reduced gray matter volume (38). We reported in a single candidate gene study that the IL-6-174 C allele was associated with a 2.5-fold elevated risk of CP (5), suggesting that an altered fetal inflammatory response because of genetic variation in inflammatory genes could contribute to a higher risk of CP $(4,8)$. However, none of the other cytokine gene variants in this study were significantly associated with CP.

Given the limited sample size, it is possible that our negative results reflect type 2 error because of lack of statistical power, rather than the absence of a true genetic association. Our power analyses suggest that we had adequate power to detect previously described effect sizes for six of the polymorphisms studied (s: eNOS, MBL 52, MTHFR 677, MTHFR 1298, and apoE E2 and E4 alleles), and thus our negative findings for these genes, excepting the apoE E4 allele, are relatively robust. Our study had only marginal or poor power to detect previously described associations in all other genetic polymorphisms. Therefore, these other negative findings should be interpreted with caution pending further evaluation in other populations.

Despite the growing number of studies evaluating genetic risk factors for $\mathrm{CP}$, the contribution of genetic factors to $\mathrm{CP}$ is likely to be small. The risk of recurrent isolated CP following a first affected child was $0.5 \%$ in a US population (39). Among children with $\mathrm{CP}$ not due to a brain malformation, genetic syndrome, or neurometabolic disease, the recurrence risk is likely to be even smaller. Given the relatively common population occurrence of genetic polymorphisms, and the relatively rare occurrence of CP in term infants, it is unlikely that successful preventative measures will be developed based on genetic risk factors alone, unless we can identify strong gene-environment interactions that confer a significantly increased risk of $\mathrm{CP}$, or we can identify combinations of genetic variants that together signify a particularly high risk of $\mathrm{CP}$. Our data support the evidence that the contribution of genetic factors to CP is likely to be small. Very large-scale studies of genetic, environmental, and obstetric factors will be needed before effective preventative strategies can be devised.

Acknowledgments. We thank Lauren Weiss for her insights regarding statistical analysis, and Judith Grether, Martin Kharrazi, and Steven Graham for their assistance with blood spot retrieval.

\section{REFERENCES}

1. Mutch L, Alberman E, Hagberg B, Kodama K, Perat MV 1992 Cerebral palsy epidemiology: where are we now and where are we going? Dev Med Child Neurol 34:547-551

2. O'Callaghan ME, MacLennan AH, Haan EA, Dekker G 2009 The genomic basis of cerebral palsy: a huge systematic literature review. Hum Genet 126:149-172

3. Wu D, Zou YF, Xu XY, Feng XL, Yang L, Zhang GC, Bu XS, Tang JL 2011 The association of genetic polymorphisms with cerebral palsy: a meta-analysis. Dev Med Child Neurol 53:217-225

4. Djukic M, Gibson CS, Maclennan AH, Goldwater PN, Haan EA, McMichael G, Priest K, Dekker GA, Hague WM, Chan A, Rudzki Z, Van Essen P, Khong TY, Morton MR, Ranieri E, Scott H, Tapp H, Casey G 2009 Genetic susceptibility to 
viral exposure may increase the risk of cerebral palsy. Aust N Z J Obstet Gynaecol 49:247-253

5. Wu YW, Croen LA, Torres AR, Van De Water J, Grether JK, Hsu NN 2009 Interleukin-6 genotype and risk for cerebral palsy in term and near-term infants. Ann Neurol 66:663-670

6. Gibson CS, Maclennan AH, Dekker GA, Goldwater PN, Sullivan TR, Munroe DJ, Tsang S, Stewart C, Nelson KB 2008 Candidate genes and cerebral palsy: a population-based study. Pediatrics 122:1079-1085

7. Gibson CS, MacLennan AH, Goldwater PN, Dekker GA 2003 Antenatal causes of cerebral palsy: associations between inherited thrombophilias, viral and bacterial infection, and inherited susceptibility to infection. Obstet Gynecol Surv 58:209-220

8. Gibson CS, MacLennan AH, Goldwater PN, Haan EA, Priest K, Dekker GA; South Australian Cerebral Palsy Research Group 2006 The association between inherited cytokine polymorphisms and cerebral palsy. Am J Obstet Gynecol 194:674.e1674.e11

9. Gibson CS, MacLennan AH, Goldwater PN, Haan EA, Priest K, Dekker GA; South Australian Cerebral Palsy Research Group 2008 Mannose-binding lectin haplotypes may be associated with cerebral palsy only after perinatal viral exposure. Am J Obstet Gynecol 198:509.e1-509.e8

10. Gibson CS, MacLennan AH, Hague WM, Haan EA, Priest K, Chan A, Dekker GA; South Australian Cerebral Palsy Research Group 2005 Associations between inherited thrombophilias, gestational age, and cerebral palsy. Am J Obstet Gynecol 193:1437

11. Nelson KB, Dambrosia JM, Iovannisci DM, Cheng S, Grether JK, Lammer E 2005 Genetic polymorphisms and cerebral palsy in very preterm infants. Pediatr Res 57:494-499

12. Senbil N, Yuksel D, Yilmaz D, Gurer YK 2007 Prothrombotic risk factors in children with hemiplegic cerebral palsy. Pediatr Int 49:600-602

13. Fattal-Valevski A, Kenet G, Kupferminc MJ, Mesterman R, Leitner Y, Rimon E, Harel S, Hassner A 2005 Role of thrombophilic risk factors in children with non-stroke cerebral palsy. Thromb Res 116:133-137

14. Cheng X, Li T, Wang H, Zhu D, Ma C, Ma B, Wang Y, Zhang J, Guo L, Wang L, Yun L, Chen S, Jiang Z, He L, Zhu C, Xing Q 2011 Methylenetetrahydrofolate reductase gene polymorphisms and cerebral palsy in Chinese infants. J Hum Genet $56: 17-21$

15. Meirelles Kalil Pessoa de Barr, Rodrigues CJ, de Barros TE, Bevilacqua RG 2000 Presence of apolipoprotein E epsilon4 allele in cerebral palsy. J Pediatr Orthop 20:786-789

16. Kuroda MM, Weck ME, Sarwark JF, Hamidullah A, Wainwright MS 2007 Association of apolipoprotein e genotype and cerebral palsy in children. Pediatrics 119:306-313

17. McMichael GL, Gibson CS, Goldwater PN, Haan EA, Priest K, Dekker GA, MacLennan AH 2008 Association between apolipoprotein e genotype and cerebral palsy is not confirmed in a caucasian population. Hum Genet 124:411-416

18. Braga LW, Borigato EV, Speck-Martins CE, Imamura EU, Gorges AM, Izumi AP, Dantas RC, Nunes LG 2010 Apolipoprotein e genotype and cerebral palsy. Dev Med Child Neurol 52:666-671

19. Krieger N 1992 Overcoming the absence of socioeconomic data in medical records: validation and application of a census-based methodology. Am J Public Health 82:703-710

20. Wu YW, Croen LA, Shah SJ, Newman TB, Najjar DV 2006 Cerebral palsy in a term population: risk factors and neuroimaging findings. Pediatrics 118:690-697
21. Wu YW, Escobar GJ, Grether JK, Croen LA, Greene JD, Newman TB 2003 Chorioamnionitis and cerebral palsy in term and near-term infants. JAMA 290:2677-2684

22. Badawi N, Watson L, Petterson B, Blair E, Slee J, Haan E, Stanley F 1998 What constitutes cerebral palsy? Dev Med Child Neurol 40:520-527

23. Grether JK, Cummins SK, Nelson KB 1992 The California cerebral palsy project. Paediatr Perinat Epidemiol 6:339-351

24. Dean FB, Hosono S, Fang L, Wu X, Faruqi AF, Bray-Ward P, Sun Z, Zong Q, Du Y, Du J, Driscoll M, Song W, Kingsmore SF, Egholm M, Lasken RS 2002 Comprehensive human genome amplification using multiple displacement amplification. Proc Natl Acad Sci U S A 99:5261-5266

25. STATA 2003 Stata Statistical Software. StataCorp., College Station, TX

26. Romero R, Kuivaniemi H, Tromp G, Olson J 2002 The design, execution, and interpretation of genetic association studies to decipher complex diseases. Am J Obstet Gynecol 187:1299-1312

27. Cardon LR, Bell JI 2001 Association study designs for complex diseases. Nat Rey Genet 2:91-99

28. Colhoun HM, McKeigue PM, Davey Smith G 2003 Problems of reporting genetic associations with complex outcomes. Lancet 361:865-872

29. Gibson CS, MacLennan AH, Goldwater PN, Haan EA, Priest K, Dekker GA 2006 Neurotropic viruses and cerebral palsy: population based case-control study. BMJ 332:76-80

30. Saunders AM, Roses AD, Pericak-Vance MA, Dole KC, Strittmatter WJ, Schmechel DE, Szymanski MH, McCown N, Manwaring MG, Schmader K, Breitner JC, Goldgaber D, Benson MD, Goldfarb L, Brown WT 1993 Apolipoprotein E epsilon 4 allele distributions in late-onset Alzheimer's disease and in other amyloid-forming diseases. Lancet 342:710-711

31. Xin XY, Song YY, Ma JF, Fan CN, Ding JQ, Yang GY, Chen SD 2009 Gene polymorphisms and risk of adult early-onset ischemic stroke: a meta-analysis. Thromb Res 124:619-624

32. McCarron MO, Delong D, Alberts MJ 1999 Apoe genotype as a risk factor for ischemic cerebrovascular disease: a meta-analysis. Neurology 53:1308-1311

33. Acevedo SF, Piper BJ, Craytor MJ, Benice TS, Raber J 2010 Apolipoprotein e4 and sex affect neurobehavioral performance in primary school children. Pediatr Res 67:293-299

34. Shen Y, Yu HM, Yuan TM, Gu WZ, Wu YD 2007 Intrauterine infection induced oligodendrocyte injury and inducible nitric oxide synthase expression in the developing rat brain. J Perinat Med 35:203-209

35. Kadhim H, Khalifa M, Deltenre P, Casimir G, Sebire G 2006 Molecular mechanisms of cell death in periventricular leukomalacia. Neurology 67:293-299

36. Forster C, Clark HB, Ross ME, Iadecola C 1999 Inducible nitric oxide synthase expression in human cerebral infarcts. Acta Neuropathol 97:215-220

37. Harding DR, Dhamrait S, Whitelaw A, Humphries SE, Marlow N, Montgomery HE 2004 Does interleukin-6 genotype influence cerebral injury or developmental progress after preterm birth? Pediatrics 114:941-947

38. Reiman M, Parkkola R, Lapinleimu H, Lehtonen L, Haataja L 2009 Interleukin-6 174 and -572 genotypes and the volume of deep gray matter in preterm infants. Pediatr Res 65:90-96

39. Van Naarden Braun K, Autry A, Boyle C 2005 A population-based study of the recurrence of developmental disabilities-Metropolitan Atlanta Developmental Disabilities Surveillance Program,1991-94. Paediatr Perinat Epidemiol 19:69-79 